\title{
On the Actual Pursuit of Moral Education
}

\author{
Xi Fang ${ }^{1}$, Mengwen Pan $^{2}$ \\ 1. School of Philosophy and politics Law, Yunnan Normal University, Kunming650500, China; \\ 2. School of Yunnan language and culture, Yunnan Normal University, Kunming650500, China; \\ E-mail : fangxi1982@126.com
}

\begin{abstract}
The purpose of this paper is to clarify the actual pursuit of moral education, in order to teach the majority of colleagues and experts and scholars. The study shows that the return of "morality" is the premise of moral education; the true return of "education" is the foundation of moral education; and the inner harmony of life is the actual pursuit of moral education. The originality of this paper lies in the comprehensive and systematic discussion on the pursuit of moral education, which further clarifies the scientific connotation and spiritual essence of moral education. This will help us carry out the educational idea of "establishing morality and cultivating people" in the new era, and lay a solid foundation of moral environment for the realization of "Chinese Dream".
\end{abstract}

\section{Keywords-Moral Education; Life; Harmony; Pursuit}

\section{INTRODUCTION}

For a long time, we regard morality as a kind of behavior norm between people and people or between people and society, and we regard it as a kind of ideology of society, which is obviously not the moral education in "educational vision", it is a strict moral control in political vision. Moral education based on this moral concept, which emphasizes the individual's subordination to the collective, the society and the state, neglecting the individual's subjectivity in the moral field, regulating the people's daily life behavior with the consistent moral order and moral standards, and carrying out the moral restraint of the moral integration order, which is embodied in a moral control. Its potential intention is to make the educational object submit to the social or political requirements, thus forming the perfect order of the whole society. However, the morality is different from religion, "the foundation of morality is the self-discipline of human spirit, while the foundation of religion is the heteronomy of human spirit".[1] That is to say, the morality suitable for human beings should be based on human nature, because the moral education of self-discipline based on human nature is the moral choice for the purpose of one's own goodness and happiness, and it can really cultivate human morality.

\section{THE "MORAL" PREMISE OF MORAL EDUCATION}

Objective evaluation of current moral education in China can be summed up with the term "low effectiveness". So, what is the reason for this unoptimistic moral education? On the one hand, it is mainly due to the confusion between "morality" and "ethics". That is to say, we must first clear up the "morality" and put morality in human nature, that is, the premise of moral education is that the "morality" is anti-original to the truth. Specifically, as the core category of ethical science, morality and ethics have their own internal characteristics, which determines the difference between them. In Laozi's view, the secular moral standard belongs to the category of ethics, and only the moral realm which accords with human's "simple" nature can be called morality. In Hegel's view, morality is mainly related to 'ought' and spread in forms such as conscience. Ethics, on the other hand, involves the family, civil society, the state and other social structures. "[2] Specifically, from the established subject, the ethical maker is the society, that is, the society put forward to its members of the "ought" meaning of behavior norms. It is a kind of social legislation and a special expression of social value system, But the person who establishes morality is the individual, that is, the self legislation of each behavior subject is a special expression of personal value belief. In terms of functional dimensions, the meaning of ethics mainly lies in providing a kind of behavior pattern and value orientation for the members of the society; and morality mainly reflects its own value meaning by encouraging the main body of behavior to pursue the good, it is through providing the power of people's behavior to support the system to make it reach a certain realm of life. In terms of hierarchy, ethics is a universal law that members of society must accept. Once established, it embodies the inevitability of iron and presents a unitary character. But the difference of people's moral realm further determines the difference of people's moral choice. It can be seen that ethics is to be grasped from a social point of view, while morality must be implemented into the spiritual world of individual; morality is the individualization of ethics, and ethics is the socialization of morality; morality exists for human being, and morality is the form of human life. Therefore, the education of human life, respecting the characteristics of life and promoting the value process of good life based on the original morality must be the premise of moral education. 
On the other hand, because of the alienation of morality itself, specific performance can be summarized as three points: one is to propagate the role of law and system too much. That is, the law and the system are on the premise of the theory of original evil of humanity, from outside to impose mandatory restrictions and precautionary provisions on human behavior, while morality is based on the theory of goodness of humanity, which is the realization of the inner self expectation of a subject through certain actions. However, if the propaganda of the law makes people form a misleading consciousness, once the protection of the law is obtained, the deterrent power of the legal system will be transformed into a powerful motive force for its own behavior, and the subject will have no scruples because it does not need moral support, and the moral scope is actually narrowing down step by step. The purpose of moral institutionalization is to eradication moral decline, and in fact become an intermediary between morality and law. The principle of rule of law in the name of morality seems to expand the scope of morality, but in essence it is the gradual impracticable establishment of morality, and moral alienation is the result of gradual loss of morality. Two is that we must be strict with the whole society and relax the requirements of individual quality. That is, people magnify the injustices existing in the whole society, the voice of fairness and efficiency is higher than the demand for personal quality, and people begin to be ambiguous about the moral principles they believed in the past. People do not look at the reason of moral phenomenon from the individual itself, but attribute it to the incompetence of the society as a whole, and do not examine the reason of the moral phenomenon from the individual itself, but attribute it to the incompetence of the society as a whole. With the development of science, all kinds of immoral behavior can be found in psychology, physiology and other subjects, and understood as the excuse for forgiveness, as a result, moral dignity is weak in the face of immoral behavior, and moral alienation is increasingly manifested as a deviation from means. Three is that the moral evaluation mechanism is inaccurate. That is to say, sound and stable moral evaluation is bound to contribute to the formation of good social morality, and on the contrary is not. The importance of the problem is that this misalignment is not the misalignment of content, but the failure of communication channels between individuals and society. The deviations from behavior and orally make social public opinion, traditional habits and inner beliefs incorrectly conveyed and feedback information, resulting in the loss of strength as a moral evaluation system as a powerful spiritual force, which is the manifestation of moral alienation. Obviously, sublation of moral alienation is bound to highlight the significance of morality itself through moral construction, which is more and more close to the expected goal of morality. That is to say, only when we have moral integrity, can we explore moral education without deviating from the true nature of moral education.

\section{THE "EDUCATION" FOUNDATION OF MORAL EDUCATION}

Studying the root cause of the moral crisis, we have to admit that there are waves of economic and scientism in the society, have appeared the "pathological" phenomenon which was Dewey called, or have called the "negative function of education" and "anti-education" phenomenon. Our educational concepts and policies are far from the requirements of the allround development of all students. Our education focuses on the selection of the elite, and the design of each educational content and link is mainly for some people to move up to a higher level of school, and test scores become the only criterion for measuring students' merits and demerits. "[3] That is to say, the basic characteristic of this education is utilitarianism, its purpose is economic utility, its means is instrumental rationality, it only teaches students how to live, but they do not discuss with them the right to life, the meaning and purpose of life. In fact, education has been divorced from the origin of life. What I want to emphasize here is that moral education itself does have some problems that can not be ignored. But the problem lies not only in moral education itself, but also in the misdirection of school education as a whole, which leads to the loss of its ultimate goal. It deviates from its true meaning fundamentally and becomes a kind of utilitarian education under the operation of instrumental rationality."If a country wants to compete vigorously with the Soviet Union on economic and military fronts, schools should spend less time in 'soft' fields such as moral education, and more time on academic topics, and democracy depends more on the number of national products and nuclear warheads than on the moral self-discipline of individuals."[4] "For the purposes of science technology economy and military, people are willing to put enormous financial resources on education, but whether in the Soviet Union or the West, the evaluation of scientific value and the evaluation of spiritual value cannot be compared."[5] Such as some economic utilitarianism school education, in fact, it has been completely accepted by Chinese education and has been continuously strengthened. The school becomes the factory that produces "standard parts" or "labor force", the emotions, ideas, and moral qualities of all people are precisely measured here, and all people's destinies are calculated by the degree to which they conform to scientific testing standards."Human" gradually becomes blurred and fragmented in education, on the contrary, the accuracy and logic representing the "scientific nature" become clearer and clearer.

In other words, the above utilitarian education exacerbates the exhausted soil of moral education. The fundamental reason why the state of moral education is not optimistic lies not in the moral education itself, but in the utilitarian orientation of the existing education. If we do not fundamentally rethink and make changes, so that how we stress on the importance of moral education will eventually lead to a the wrong direction. Because the key to examination-oriented education, which is concentrated in utilitarian education, is not only to cultivate a number of "examination machines" with "high marks and low abilities," what is even more fatal is that education draws people into a "utilitarian field" from an early age, leading them to the path of striving hard for personal, material and realistic utilitarianism. This not only can not make people become human, but may finally put people on the road to ruin. When 
people talk about "invigorating the country by science and education", "creative talents", "knowledge economy", and so on, the function of education is often overpraised, which is deducted from the economic function of education, the quality of talents and so on. The worship of scientific reason led to the banishment of value rationality. It just is like the human created the gods, and then under the control of the gods, human created science and technology and was then tamed by science and technology. In other words, human beings' own scientific and technological rationality has become their own force of alienation, controlling people's thought and behavior, so the human thought has lost its brilliant color and become the program of pattern and mechanization. In this age of technological tools controlling everything, all values and rationality in human life are overshadowed by its brilliant reflection. Everything in life has been modelled and instrumented, and even man himself has become a tool for economic prosperity and a puppet for scientific and technological progress. Education only enables people to see the utilitarian in front of them, and even to do anything for it; the fundamental task of education is to teach and learn knowledge and skills. It is the most important thing to let students understand the external material world and acquire the ability to meet the needs of life, so moral learning is insignificant; education becomes the "maid" of political economy at the social level, and at the personal level, it becomes a tool for seeking fame and wealth and achieving high official value; education "cover up" the true meaning of life. It only makes the road of life narrower and narrower. Therefore, only the return of human beings, the return of life has the antitruth of education, the true education is the foundation of moral education.

\section{THE "HARMONY" PURSUIT OF MORAL EDUCATION}

Through the above, life is the logical starting point and ontological basis of education, and the purpose of education is to sublimate life. Moral education points to human life, and its highest state should be the pursuit of harmony with human life, that is, the internal harmony of moral education we pursue and the pursuit of a harmonious relationship. To borrow Nordings' concept of concern: "Concern is a relationship, not what we often think of as a personal character. She treated caring as an essential condition for the creation of moral beings. Therefore, she emphasized the creation and maintenance of concern, and regarded it as the core of moral education."[6] This mode of care, starting with the moral relationship between the construction of the individual and the world around himself, is a breakthrough in the traditional moral education which focuses on the cultivation of virtue. Its idea embodies a philosophical transcendence and the thought of "human life". Based on this theory, moral education advocates that the focus of attention is on the establishment of concern, rather than the concern only as human virtue. On the basis of transcending the theory of virtue, this theory advocates that concern should be regarded as "a state of life out of a relationship rather than a set of concrete ways of behavior."[7] The corresponding moral education theory is no longer simply to make the individual form a certain virtue, but to emphasize the moral relationship between the individual and all the life in the surrounding world. Morality is a choice on the basis of value judgment on the state of a variety of relationships. Personal development and development of one's own life is between the individual and his own relationship, that is, self experience; between individual and other people, that is, interpersonal experience; between the individual and other life, that is, the experience of things; between the individual and the environment, that is, the experience between man and nature. Obviously, it is closer to the essence of human being as a moral being to guide the individual to produce virtue by the experience and construction of moral relationship. Regard morality as a kind of choice constructed by individuals; regard moral education as a process of guiding individuals to construct moral relations independently; make individuals more aware of the characteristics of being a relational entity; open up a new perspective for individuals to understand and experience morality; get rid of morality is a predicament for the external demands of individuals, which provides possibility for individuals to become autonomous moral subjects.

In particular, "if in a relationship, one of them should have an objective and systematic influence on the other party, the "I-you" attitude in this relationship will be based on an incomplete mutual relationship."[8] In this interaction, there is a lack of "human life" concern for others. According to the above theory of concern, moral concern and love do not originate from charity and gift to the weak, but is derived from the inter - subjectivity associated with human being, that is, "body nature" or "human nature", that is, when people regard the other as the same existence as the self, the relationship between the human and the other gets rid of the possessive and confrontational relationship, and becomes a symbiotic relationship. In this way, the other and I have no distinction between the subject and the object, and become the life connected with each other. Therefore, one's morality is not a virtue of one's own, not a quality that is noble to others, it is a relationship of mutual achievement in the symbiosis of the other. In this theory, those who are at the core are not caring people and people who are concerned, but a relationship which is made up of both sides. It is not the subjectivity of individual, but the intersubjectivity and class between man and man. In this way, morality is not only expressed through the words and deeds of the actors and the feelings or results of the act acceptor, but is gradually clarified and highlighted in the symbiotic relationship between the two. The moral education is no longer the ultimate purpose of what kind of behavior is made by the individual, but to help the individual learn to construct and understand the caring moral relationship with others; it is not to teach the individual to deal with the other as the Savior, the benefactor and the subject, but to connect and communicate with the other with the interrelated symbiosis. It is clear that this is a bridge of "class nature". In a moral relationship, what is associated with "me" is "you" whose like "me", and not "it" that is relative to me, because in the world of "I--it," morality, is the word of order dominated by the powerful and the strong, and for the weak, it is just a bleak world that is objectified. In short, in the Construction of moral Relations, moral education turns from "I--it" relationship to "I-you" relationship, and goes into the world of "I--you", only in this world can we discover the true morality, which is the actual pursuit of moral education. 


\section{CONCLUSION}

In all possible relationships, the mode of caring relationship starts from the nature of human nature and advocates the caring relationship between people, the influence of moral relations and the feelings of the parties involved as equal contributors to moral relations transcend the unilateral morality of the narrowness. With the "concern" of living beings as the core, moral and moral education will become friendly and dynamic. If this idea can be accepted and put into practice, it will lead and guide moral education, and the problem of low effectiveness of moral education may be solved to a certain extent. All in all, the moral education towards inner harmony is concerned with the individual life, and it also needs to guide the individual to respect the life of others, and to have profound humanistic care and ultimate concern for the whole human life, it can make a due contribution to the free development of all life. In essence, its ultimate goal is to achieve the free and allround development of all people. In this ideal level of moral education, as every "individual" of mankind. While paying attention to and extending one's life, one will consciously stand on the position of all mankind, containing the "class consciousness" that transcends feelings in the sense of individual life, containing the concern for the life of all mankind and a concern for the harmonious development of all life. All parties involved in moral relations should be included in the field of vision, and everyone can generate virtue in the construction of moral relations, then the edifice of morality will stand steadily.

\section{ACKNOWLEDGMENT}

[Foundation item] This paper is a periodical achievement of the National Social Science Fund youth project "The debate and significance of the contemporary Western Virtue Ethics and normative ethics" (project number: 17CZX054)

[About the author] Xi Fang(1982-)Male, Tongshan Hubei people, associate Professor of School of philosophy and politics law, Yunnan Normal University, master supervisor, doctor of philosophy, mainly engaged in Western Ethics Research. Mengwen Pan(1990-), Female, Yibin Sichuan people, corresponding author, teacher of School of Yunnan language and culture Yunnan Normal University, doctoral candidates in Zhongnan University of Economics and Law, Mainly engaged in the study of Marx's Ethics.

\section{REFERENCES}

[1] Marx,Engels.,"Complete works of Marx and Engels"(1), Beijing: people's publishing house,1972,pp.15.

[2] Yang Guorong,"Ethics and existence--The study of moral philosophy”,Shanghai: Shanghai people's publishing house,2002,pp.16.

[3] Yuan Guilin, "Quality education: the banner of educational and teaching reform in the 21st Century", Chinese journal of education,vol5,2001.

[4] Lu Jie, "The back to the truth of education -- the foundation of moral education", Journal of east China normal university,vol12,2001.

[5] karl jaspers,"What is education?"Zou Jin translation,Shanghai: Triple bookstore,1991,pp.50.

[6] Nell Noddings, "Educating Moral People: A Caring Alternative to Character Education", Teachers College Press,2002,pp.68.

[7] Nell Noddings, "The challenge to care in school_-an alternative approach to education", Columbia: Teacher college press of Columbia university,1992,Chapter 2.

[8] Martin Buber, "You and me", Chen Weigang translation,Shanghai: Triple bookstore,2002,pp.116. 